\title{
KONTEKS SYUKUR SEBAGAI PARADIGMA DALAM PERSPEKTIF PENDIDIKAN ISLAM
}

\author{
Moh. Fuadi \\ Sekolah Tinggi Ilmu Tarbiyah Raudhatul Ulum Sakatiga \\ Email: fuadi198505@gmail.com
}

\begin{abstract}
Abstrak
Education is a rehumanisme, that was oriented to form individuals who able to understand the reality itself and the surrounding communities. The aim of education is to create significant social change in the life of mankind. One of the contents of the national education goals is to appreciate the reality of humanity and the potential that owned learners (human). Islam in its victorius was a center of the study of various discipline. It was proved by the emergence of Muslim scientists. But over time, the Islamic intellectualism began to decline along with cultural understanding and taqlid, whereas alQur'an have many signaled to examines all disciplines, not limited to the religious sciences. It can be seen from the verses of al-Qur'an that ordered to examine the verses kauniyah. Thus Islamic comprehensive assessment is a paradigm of Humanist Islamic Education or in other words, humanize human accordance with the primary task of man as a khalifah on earth. Keywords: Islamic Education, Paradigm, and Humanist.
\end{abstract}

Kata Kunci: Syukur, Parafigma, Pendidikan, Islam

\section{Pendahuluan}

Syukur pada umumnya dipahami oleh masyarakat sebagai kegiatan serimonial yang diadakan oleh seorang atau kelompok dengan cara mengundang masyarakat dan berkumpul bersama dalam suatu tempat untuk membaca ayat-ayat al-Qur'an, berdo'a, lalu diberikan makanan. Kegiatan syukuran ini tidaklah salah, namun sesungguhnya makna syukur tidak hanya sekedar ritualitas belaka, tanpa implikasi nyata dalam kehidupan.

Dalam kegiatan tersebut memaknai syukur menjadi tidak utuh, kurang sesuai dengan kata syukur yang telah dirumuskan para ulama berdasarkan al-Qur'an dan as-Sunnah. Muhammad Abduh misalnya sebagaimana dikutip oleh Muhaimin (2004: 16) menunjukkan bahwa yang dikatakan syukur itu adalah menggunakan nikmat Alllah sesuai dengan fungsi dan kehendak yang menganugerahkannya, yaitu Allah. Senada dengan pendapat Abduh, Abdulrahim (2002:37-38) memaknai syukur sebagai pemanfaatan nikmat Allah sesuai dengan fungsi, tempat dan situasi secara optimal. Tindakan syukur akan menyebabkan nikmat Allah bertambah, atau berdampak pada nilai tambah atau added value. Karena itu, belum bersyukur seseorang bila tidak menimbulkan nilai tambah dalam bentuk apapun. Maka indikator syukur adalah adanya nilai tambah sebagai akibat dari usaha seorang yang bersyukur. Hal ini ditegaskan dalam al-Qur'an QS. Ibrahim (14) ayat 7: “Dan (ingatlah juga), tatkala Tuhanmu memaklumkan: menambah (nikmat) kepadamu, dan jika kamu mengingkari (nikmat-Ku), maka sesungguhnya azab-Ku sangat pedih". ${ }^{1}$

\footnotetext{
${ }^{1}$ Raudhah, Vol 2 no 1 (2018) | 2
} 


\section{Konteks Syukur Sebagai Paradigma Dalam Perspektif Pendidikan Islam} Moh. Fuadi

Filosofi syukur bersumber dari pandangan bahwa nikmat Allah yang telah dianugerahkan kepada manusia tidak terhitung banyaknya, manusia tak akan mampu mengitung-hitungnya. Diantara nikmat Allah antara lain potensi jasmani dan rohani, serta alat-alat potensial lainnya, yaitu pendengaran, penglihatan, hati, dan akal. Hal tersebut sebagaimana ditegaskan dalam al-Qur'an, antara lain dalam QS. Al-Hajj (22) ayat 46:

Maka apakah mereka tidak berjalan di muka bumi, lalu mereka mempunyai hati yang dengan itu mereka dapat memahami atau mempunyai telinga yang dengan itu mereka dapat mendengar? Karen Sesungguhnya bukanlah mata itu yang buta, tetapi yang buta ialah hati didalam dada.

Dalam konteks inilah pendidikan berperan penting dalam usaha pengembangan segenap potensi manusia, sehingga mereka mampu menjalankan peranannya di dunia ini, baik sebagai hamba Allah ('Abdullah) maupun Khalifah-Nya, sebagaimana dijelaskan dalam QS. AlBaqarah (2) ayat 30:

Ingatlah ketika Tuhanmu berfirman kepada para malaikat "Sesungguhnya Aku hendak menjadikan seorang khalifah di muka bumi." mereka berkata: "Mengapa engkau hendak menjadikan (khalifah) di bumi itu orang yang akan membuat kerusakan padanya dan menumpahkan darah, padahal kami senantiasa bertasbih dengan memuji Engkau dan mensucikan Engkau?" Tuhan berfirman: "Sesungguhnya aku mengetahui apa yang tidak kamu ketahui."

Melihat kenyataan diatas, dibutuhkan suatu perubahan paradigma atau mind set masyarakat tentang hakikat syukur dengan tetap mengacu pada rumusan para ulama serta alQur'an dan as-Sunnah. Hal ini sebagaimana pendapat Filosof Thomas Kuhn (2005: 10), yang mengungkapkan: apabila tantangan-tangtangan baru dihadapi dengan menggunakan paradigma lama, segala usaha yang dijalankan akan menemui kegagalan. Selanjutnya, konsep syukur tersebut dapat di konstruksi sebagai paradigma pendidikan dalam perspektif Islam. ${ }^{2}$

Berdasarkan pemaparan diatas, penulis berupaya untuk menjabarkan persoalan syukur sebagai perspekstif dalam pendidikan Islam, berangkat dari masalah tentang: pengertian perspektif pendidikan Islam, dan komponen syukur, dan bagaimanakah perpekstif syukur di konstruksi dalam pendidikan Islam?

Berdasarkan pemaparan diatas, penulis berupaya untuk menjabarkan persoalan syukur dalam perpekstif pendidikan Islam, berangkat dari masalah tentang: perpekstif pendidikan Islam, dan komponen syukur, dan bagaimanakah perpekstif syukur di konstruksi kedalam pendidikan Islam?

\section{Komponen Syukur}

Kata "syukur" berasal dari bahasa Arab, yaitu sin, kaf, dan ra. Menurut Munawir (t.th: 734), kata ini mengandung arti berterima kasih kepada, pujian, atau ucapan, atau pernyataan terima kasih. Sedangkan al-Isfahani sebagaimana di kutif oleh Shihab (2006: 215) mengartikan kata syukur sebagai gambaran yang terbentuk dalam benak tentang nikmat dan menampakkannya ke permukaan.

Yang dimaksud dengan paradigma dalam makalah ini adalah seperti yang dipahami oleh Thomas Khun bahwa pada dasarnya realitas sosial itu dikonstruksian oleh mode of thought atau mode inquiry tertentu, yang pada gilirannya akan menghasilkan mode of

\footnotetext{
${ }^{2}$ Raudhah, Vol 3 no 1 (2018) |3
} 
Volume 3 Nomor 2 Edisi Desember 2018

P-ISSN : 2541-3686

knowing (cara mengetahui) tertentu pula. Paradigma sebagai contoh yang diterima tentang praktik ilmiah sebenarnya, termasuk hukum, teori, aplikasi, dan instrumentasi secara bersama-sama yang menyediakan model yang dirinya muncul tradisi yang koheren dari penelitian ilmiah.

Pandangan ini berbeda dengan pandangan ulama umumnya yang menjelaskan syukur berasal dari kata "syakara" yang berarti membuka yang dilawan dengan kata "kupur" yang berarti "menutup atau melupakan segala nikmat dan menutup-nutupinya.

Pengertian kebahasaan diatas tidak sepenuhnya sama dengan pengguaan-Nya dalam alQur'an atau dalam istilah keagamaan. Menurut Shihab (2006: 2015) kata syukur dengan berbagai bentuknya ditemukan sebanyak enam puluh empat kali. Mengutif Ahmad Ibnu Faris dalam bukunya Maqayis al-Lughah, Sihab mengungkapkan empat arti dasar dari yang di peroleh. Hakikatnya adalah merasa ridha atau puas dengan sedikit sekalipun, karena itu bahasa menggunakan kata ini (syukur) untuk kuda yang gemuk namun membutuhkan sedikit rumput; kedua, kepenuhan dan dan kelebatan. Pohon yang tumbuh subur di lukiskan dengan kalimat shakarat al-shajarat; ketiga, sesuatu yang tumbuh di tangkai pohon (parasit); ke empat, pernikahan, atau alat kelamin. ${ }^{3}$

Makna-makna dasar tersebut dapat juga diartikan sebagai penyebab dan dampak, sehingga kata syukur mengisyaratkan siapa yang merasa puas dengan yang sedikit, maka ia akan memperoleh banyak, lebat, dan subur (Shihab, 2006:216). Makna ini di perkuat dengan beberapa ayat al-Quran yang mempertentangkan syukur dengan kufur, antara lain QS. Ibrahim (14) ayat 7: "Dan (ingatlah juga), tatkala Tuhan-Mu memaklumkan, "Sesungguhnya jika kamu bersyukur pasti akan Kutambah (nikmat-Ku amat pedih.)"

Demikian juga dengan redaksi pengakuan Nabi Sulaiman yang di abadikan al-Quran dalam QS. Al-Naml (27) ayat 40:

Berkatalah seorang yang mempunyai ilmu dari al-Kitab:"Aku akan membawa singgasana itu kepadamu sebelum matamu berkedip". Maka tatkala Sulaiman melihat singgasana itu terletak di hadapannya, iapun berkata: ini termasuk kurnia Tuhanku untuk mencoba Aku apakah Aku bersyukur atau mengingkari (akan nikmat-Nya). Dan barangsiapa yang bersyukur maka sesungguhnya dia bersyukur untuk (kebaikan) dirinya sendiri. Dan barang siapa yang ingkar, maka sesungguhnya Tuhanku maha kaya lagi maha mulia”.

Agaknya kedua makna terakhir ini dapat dikembalikan dasar pengertiannya kepada kedua makna terdahulu. Makna ketiga sejalan dengan makna pertama yang menggambarkan kepuasan dengan yang sedikit sekalipun, sedang makna keempat dengan makna kedua, karena dengan pernikahan (alat kelamin) dapat melahirkan banyak anak.

Tuhan untuk mencoba aku bersyukur atau mengingkari (akan nikmat-Nya). Dan

barangsiapa yang bersyukur maka sesungguhnya dia bersyukur untuk (kebaikan) dirinya sendiri dan barangsiapa yang ingkar, maka sesungguhnya Tuhanku maha kaya lagi maha mulia".

Shihab (2006: 216-217) menyimpulkan bahwa hakikat syukur adalah menampakkan nikmat, dan hakikat kupur adalah menyembunyikannya. Menampakkan nikmat antara lain berarti menggunakannya sesuai dengan yang di kehendaki oleh pemberinya, juga menyebut nikmat dan pemberi secara lisan. Dengan demikian syukur mencakup tiga komponen penting,

\footnotetext{
${ }^{3}$ Raudhah,Vol 4 no 1 (2018)|4
} 


\section{Konteks Syukur Sebagai Paradigma Dalam Perspektif Pendidikan Islam \\ Moh. Fuadi}

yaitu: pertama, syukur dengan hati, berupa puas secara batin atas anugerah; kedua, syukur dengan lisan, berupa pengakuan, lisan atas anugerah dan memuji pemberinya; ketiga, syukur dengan perbuatan, yaitu dengan memanfaatkan anugerah yang di peroleh sesuai dengan tujuannya.

Madjid (2000: 99-100) menjelaskan bahwa syukur ialah sikap penuh rasa terimakasih dan penghargaan, dalam hal ini atas segala nikmat dan karunia yang tidak terbilang banyaknya, yang dianugerahkan Allah kepada kita. Sikap syukur sebenarnya sikap optimis kepada hidup ini dan pandangan senantiasa mengharap kepada Allah. Karena itu sikap syukur kepada Allah sesungguhnya ditunjukkan kepada diri sendiri (QS. Lukman (31): 12), karena manfaat besar kejiwaannya yang akan kembali kepada yang bersangkutan. ${ }^{4}$

Abdulrahim (2002:37) mengemukakan bahwa bersyukur mengandung dua macam komponen aktivitas, yaitu perkataan dan perbuatan. Bersyukur kepada Allah dengan lisan ialah mengucapkan kalimat Alhamdulillah. Jika ucapan ini keluar dari hati yang ikhlas tentu diiringi pula oleh perbuatan. Oleh karena itulah maka diwajibkan kepada setiap muslim menyesuaikan tingkah lakunya dengan ucapannya, jika tidak maka ia akan di golongkan dalam kelompok munafiqin. Kemurkaan Allah sangat dahsyat bagi mereka yang tak dapat menyesuaikan perbuatan atau tingkah lakunya dengan ucapannya. Sebagaimana firman Allah dalam QS. Al-Saf (61) ayat 3: "Sesungguhnya besar dosanya di sisi Allah jika kamu mengatakan sesuatu tetapi tidak kamu lakukan."

Adapun bersyukur dalam bentuk perbuatan ialah memanfaatkan nikmat Allah sesuai dengan fungsinya serta sesuai pula dengan tempat dan situasinya, dan secara optimal. Tindakan bersyukur pasti akan menjadikan nikmat Allah itu akan bertambah, tindakan bersyukur itu pasti menimbulkan "nilai tambah". Jadi kita belumlah bersyukur jika tindakan kita yang biasa dinamakan "syukuran" itu tidak menimbulkan nilai tambah dalam bentuk apapun (Abdulrahim, 2002:37-38).

Berdasarkan penjelasan diatas, jelaslah bahwa bersyukur yang ditujukan kepada Allah, juga akan mendatangkan manfaat yang besar bagi manusia. Sebagaimana telah dikemukakan dalam QS. An-Naml (27) ayat 40, di atas, dan juga QS. Luqman (31) ayat 12:

Dan sesungguhnya telah kami berikan nikmat kepada Luqman,

yaitu: "Bersyukurlah kepada Allah. Dan barang siapa yang bersyukur (kepada Allah), maka sesungguhnya ia bersyukur untuk dirinya sendiri; dan barang siapa yang tidak bersyukur, Maka sesungguhnya Allah Maha Kaya lagi Maha terpuji”.

Ayat diatas jelas memperlihatkan bahwa syukur berdampak pada manusia sendiri, bahwa fungsi syukur tidak sedikitpun tertuju kepada Allah, justru karena kemurahan-Nya Allah akan menganugerahkan kepada manusia yang bersyukur tambahan nikmat yang berlipat ganda (Shihab, 2006: 219). ${ }^{5}$ Hal ini penting untuk disadari sebagai motivasi dalam mengingatkan syukur secara produktif.

Menurut Shihab (2006: 219-220) terdapat tiga cara dalam bersyukur, yaitu melalui hati, lidah, dan anggota tubuh. Syukur dengan hati dilakukan dengan menyadarkan sepenuhnya bahwa nikmat yang di peroleh semata-mata anugerah dan kemuliaan Ilahi. Syukur dengan hati ini mengantarkan manusia dapat menerima semua anugerah Allah dengan penuh keikhlasan. Orang yang tidak dapat bersyukur dalam hal ini dikatakan sebagai kufur nikmat, sebagaiman perbuatan Qarun digambarkan dalam QS. al- qashash (28) ayat 76:

Sesungguhnya qarun adalah termasuk kaum Musa, Maka ia berlaku aniaya terhadap mereka, dan kami telah menganugerahkan kepadanya perbendaharaan

\footnotetext{
${ }^{4}$ Raudhah, Vol 5 no 1 (2018) $\mid 5$

${ }^{5}$ Raudhah, Vol 6 no 1 (2018) | 6
} 
Volume 3 Nomor 2 Edisi Desember 2018

P-ISSN : 2541-3686

harta yang kunci-kuncinya sungguh berat di pikul oleh sejumlah orang yang kuat. (ingatlah) ketika kaumnya berkata kepadanya: "Janganlah kamu terlalu bangga; sesungguhnya Allah tidak menyukai orang-orang yang terlalu membanggakan diri”.

Syukur dengan lidah dilakukan dengan mengakui ucapan bahwa sumber nikmat adalah Allah, seraya memuji-Nya dengan ucapan Alhamdulillah. Sedangkan syukur dengan perbuatan adalah bekerja dengan menggunakan nikmat yang di peroleh sesuai dengan tujuan penciptaan dan penganugerahannya (Shihab, 2006: 220-220). Sebagaimana firman Allah dalam QS. Saba' (34) ayat 13:

Para Jin itu membuat untuk Sulaiman apa yang dikehendakinya dari gedunggedung yang tinggi, patung-patung dan piring-piring yang (besarnya) seperti kolam dan periuk yang tetap (berada diatas tungku). Bekerjala hai keluarga daud untuk bersyukur (kepada Allah). Dan sedikit sekali dari hamba-hambaku yang berterima kasih.

Pada dasarnya segala nikmat yang diperoleh manusia harus di syukuri, karena nikmat yang Allah anugerahkan kepada manusia sangatlah banyak, sehingga dalam al-Qur'an QS.Ibrahim (14) ayat (14) ayat 34, Allah berfirman:

Dan Dia telah memberikan kepadamu (keperluan) dan segala apa yang kamu mohonkan kepadanya. Dan jika kamu menghitung nikmat Allah, tidaklah dapat kamu menghinggakannya. Sesungguhnya manusia itu, sangat zalim dan sangat megingkari (nikmat Allah).

Artinya semua nikmat yang telah diberikan kepada manusia wajib di syukuri, seperti kehidupan dan kematian, pengampunan-Nya, panca indra, akal, rezeki, kemerdekaan, dan lain sebagainya. Inilah pengertian dari kalimat Alhamdulillah dalam QS. al-fatihah (1) ayat (2). Ayat ini oleh Ghazali (2004: 1) di tafsirkan sebagai bentuk pemujaan terhadap keagungan, pujian terhadap Allah, dan ungkapan syukur kepada Allah, karena semua kemurahan dan kelembutan-Nya. ${ }^{6}$

Bersyukur kepada Allah wajib dilakukan manusia baik dalam kehidupan di dunia ini ataupun di kehidupan akhirat kelak (Shihab, 2006: 231-232). Hal ini telah di indikasikan dalam al-Qur'an QS. Saba' (34) ayat 1: Segala puji bagi Allah yang di miliki apa yang di langit dan apa yang ada di bumi dan bagi-Nya (pula) segala puji di akhirat. Dan dia-lah yang Maha Bijaksana lagi maha mengetahui.

Dalam konteks ini, maka segala aktivitas manusia di siang ataupun di malam hari dalam kehidupan dunia harus mencerminkan rasa syukur kepada Allah, artinya waktu manusia untuk bersyukur tidaklah terbatas, sebagaimana di gambarkan dalam QS. ar-Rum (30) ayat 17-18: "Maka bertasbilah kepada Allah dimana kamu berada di waktu subuh, dan bagi-Nyalah segala puji di langit dan di bumi dan di waktu kamu berada di waktu petang hari dan kamu berada di waktu zuhur".

Karena itulah dalam setiap aktivitasnya seorang mukmin di anjurkan untuk berdoa sebagai bentuk manivestasi atas nikmat yang telah Allah berikan kepadanya. Mulai darai bangun tidur hingga tidur lagi, tidak ada aktivitas seorang mukmin yang lepas dari doa (Shihab, 2006: 231-234). 


\section{Konteks Syukur Sebagai Paradigma Dalam Perspektif Pendidikan Islam \\ Moh. Fuadi}

\section{Paradigma Pendidikan Islam}

Paradigma secara teknis pertama kali di perkenalkan oleh Thomas Khun (1970), menurutnya paradigma pada dasarnya merupakan cara melihat sesuatu, melalui asumsi yang di bangun untuk mendekati suatu masalah keilmuan. Karena itu, menurut Lacey (1996:243) dalam A Dictionary of Philosophy, paradigma merupakan world view yang dapat digunakan untuk mengukur berbagai hal. Ketika suatu paradigma muncul, ia melingkupi seluruh sistem kemanusiaan termasuk sains dan masyarakat. Karena itu, menurutnya, paradigma dapat dikatakan sebagai teori tentang segala sesuatu.

Dihubungkan dengan pendidikan Islam, maka paradigma pendidikan Islam dapat di terjemahkan sebagai perangkat konsep atau ide yang mendasari dan menjadikan wujud terwujudnya proses pendidikan menurut ajaran Islam, yaitu proses untuk mendewasakan anak, atau mengalihkan pengetahuan, pengalaman, kecakapan, dan keterampilan kepada generasi muda, agar mereka siap mengahadapi fungsi hidupnya (Shaleh, 2008: 55).

Berdasarkan bahasan di atas maka dapat dikatakan bahwa paradigm pendidikan Islam merupakan asumsi, konsep, ataupun nilai-nilai yang digunakan atau menjadi dasar dalam melaksanakan pendidikan Islam. ${ }^{7}$ Di mana paradigma Islam menjadi acuan dalam proses pendidikan sesuatu dengan ajaran dan nilai-nilai Islam. Diantara satu paradigma yang di ambil dari ajaran Islam adalah syukur.

\section{Konsep Syukur Sebagai Paradigma Pendidikan Islam}

Untuk memahami bagaimana syukur dapat menjadi paradigma pendidikan Islam, maka dibutuhkan penelisikan awal tentang pendidikan Islam sendiri, kemudian awal dilanjutkan dengan bahasan tentang syukur sebagai motivasi pengembangan potensi yang dimiliki manusia, hingga akhirnya dapat menjadi bangunan dalam menjadikan syukur sebagai paradigma pendidikan Islam.

Dalam Islam dikenal beberapa istilah yang terkait dengan pendidikan, yaitu: al-ta'lim, al-ta'dib, dan al-riyadhah. Al-Raghib al-Isfahani salah seorang yang dikenal sebagai pakar bahasa al-Qur'an, menulis dalam al-Mufradat fi Gharib al-Qur'an, bahwa makna asal kata al-rabb adalah al-tarbiyah, yaitu memelihara sesuatu sedikit demi sedikit hingga sempurna. Senada dengan pendapat terdahulu, Imam al-Baidawi (wafat $685 \mathrm{H}$ ) mengemukankan bahwa sesuatu sedikit demi sedikit. Semetara Abdurrahman al- Bani (wafat $502 \mathrm{H}$ ) menjelaskan bahwa taribiyah terdiri atas empat unsur, yaitu: (1) menjaga dan memelihara fitrah anak menjelang baligh; (2) mengembangkan seluruh potensi dan kesiapan yang bermacam-macam; (3) mengarahkan seluruh fitrah dan potensi manusia menuju kepada kebaikan dan kesempurnaan, serta; (4) proses yang dilaksanakan secara bertahap (al-Nahlawi, 1992: 3132).

Al-Maraghi (t.th: 27) membagi kegiatan at-tarbiyah dalam dua klasifikasi, yaitu: tarbiyah khalqiyah dan tarbiyah diniyah tahzibiyyah. Tarbiyah khalqiyah merupakan proses penciptaan, pembinaan, dan pengembangan jasmani peserta didik agar dapat dijadikan sebagai sarana bagi pengembangan jiwa; sedangkan tarbiyah diniyah tahzibiyyah, merupakan proses pembinaan jiwa manusia dan kesempurnaan nya melalui petunjuk wahyu Ilahi. Berdasarkan pembagian tersebut, maka ruang lingkup at-tarbiyah mencakup berbagai kebutuhan manusia, baik jasmani dan rohani, kebutuhan dunia dan akhirat, serta kebutuhan terhadap kelestarian diri sendiri, sesamanya, alam lingkungan dan relasinya dengan Tuhan.

Al-Abrasyi (t.th: 100) memberikan pengertian bahwa tarbiyah adalah mempersiapkan manusia supaya hidup dengan sempurna dan bahagia, mencintai tanah air, tegap jasmania,

\footnotetext{
${ }^{7}$ Raudhah, Vol 8 no 1 (2018) | 8
} 
Volume 3 Nomor 2 Edisi Desember 2018

P-ISSN : 2541-3686

sempurna budi pekertinya, (akhlaknya), teratur pikirannya, halus perasaannya, mahir dalam pekerjaannya, manis tutur katanya baik dengan lisan atau tulisan. ${ }^{8}$

Sedangkan istilah ta'lim, menurut Ridha (1373 H: 262) adalah proses transmisi berbagai ilmu pengetahuan kepada jiwa individu tanpa ada batasan dan ketentuan tertentu. Pemaknaan ini didasarkan atas Q.S. al-baqarah (2) ayat 31 tentang pengajaran ('allama) Tuhan kepada Adam A.S. Kemudian menurut al-Maraghi (t.th: 82) pengajaran dilaksanakan bertahap, sebagaimana terhadap Adam mempelajari, menyaksikan dan menganalisa asmaasma yang diajarkan oleh Allah kepadanya.

Adapun istilah al-Ta'dib menurut al-attas (1988:66), al-Ta'dib adalah pengenalan dan pengakuan tempat yang tepat dari segala sesuatu yang didalamnya tatanan penciptaan sedemikian rupa, sehingga membimbing kearah pengenalan dan pengakuan kekuasaan dan keagungan Tuhan didalam tatanan wujud dan keberadaannya.

Sementara al-Ghazali yang menawarkan istilah al-riyadhah menjelaskannya sebagai proses pelatihan individu pada masa anak-anak (Bahreis, 1981:74). Berdasarkan pengertian tersebut, al-Ghazali hanya menghususkan penggunaan al-riyadhah untuk pase anak-anak, sedang fase yang lain tidak tercakup didalamnya (Ramayulis, 2008: 17).

Pandangan filosofis yang menjadi wacana publik, para ahli pendidikan bahwa proses humanisasi atau pemanusiaan (Baharudin dan Makin, 2007:19). Suatu pandangan yang mengimpikasikan proses kependidikan dengan berorientasi kepada pengembangan aspekaspek kemanusiaan manusia, baik secara fisik, biologis maupun ruhaniah, psiologis (Fadjar, 2005:181). Dengan kata lain pendidikan harus dimulai dari refleksi filosofis tentang hakikat manusia. Karena titik sentral dalam pendidikan adalah manusia.

Menurut Muttahari (1997: 30) bahwa pandangan kaum humanis belum sepenuhnya memuaskan. Memang pada diri manusia terdapat sifat-sifat yang baik dan yang buruk, tetapi karakteristis khas dari kemanusiaannya adalah iman dan ilmu (sain). Jadi yang paling penting dan mendasar yang membedakan antara manusia dan makhluk-makhluk lainnya terletak pada iman dan ilmu (sain) yang merupakan kriteria kemanusiaanya. ${ }^{9}$

Khauj (1980:62 dan 70) mengatakan bahwa aktualisasi eksistensi kemanusiaan harus mencakup dua aspek, yaitu aspek material dan aspek spiritual. Aspek spiritual merupakan bukti hubungan manusia dengan penciptanya. Hubungan ini sifatnya sangat instrinsik. Dan inilah yang membedakan antara manusia sebagai makhluk Tuhan yang mulia dengan ciptaan Tuhan yang lain.

Pendidikan harus dikembangakan sebagai pengayaan nilai-nilai spiritual dan religiusitas tanpa harus melupakan pengembangan kemampuan profesionalnya menyelesaikan masalah-masalah. (Ramly, 2005: 192). Prinsip yang digunakan dalam belajar harus mengajarkan peserta didik bagaimana dalam belajar dan menilai kegunaan belajar itu bagi dirinya.

Fadjar (2005: 181) mengemukakan bahwa pandangan filosofi klasik yang menjadi wacana publik para ahli pendidikan adalah bahwa pendidikan merupakan proses humanisasi atau pemanusiaan manusia. Suatu pandangan berorientasi kepada pengembangan aspek-aspek kemanusiaan manusia, baik secara fisik, biologis maupun ruhaniah, psikologis. Aspek fisikbiologis manusia sendirinya akan mengalami perkembangan, pertumbuhan, dan "penuaan." Sedangkan aspek ruhaniah, psikologis manusia melalui pendidikan di coba "didewasakan," didasarkan, dan "di-insan kamil-kan." Proses pendewasaan dan penyadaran dalam konteks pendidikan ini mengandung makna yang mendasar, karena bersentuhan dengan aspek paling dalam dari kehidupan manusia yaitu kejiwaan dan keruhanian; sebagai dua elemen yang berpotensi positif bagi pembangunan kehidupan yang berkebudayaan dan berkeadaan.

\footnotetext{
${ }^{8}$ Raudhah, Vol 9 no 1 (2018) |9

${ }^{9}$ Raudhah, Vol 10 no 1 (2018) | 590
} 


\section{Konteks Syukur Sebagai Paradigma Dalam Perspektif Pendidikan Islam Moh. Fuadi}

Sementara Madjid (2000: 96) menyatakan bahwa pendidikan berkisar antara dua dimensi hidup, yaitu penanaman rasa rasa taqwa kepada Allah dan pengembangan rasa kemanusiaan kepada sesama. Dengan demikian, pendidikan seharusnya mampu menumbuhkan nilai-nilai kemanusiaan universal (personality depeloment) seperti masyarakat madani, civil, civilized atau berperadaban. Pada akhirnya, akan muncul penghargaan terhadap sesama manusia, egaliterianisme, toleran dan nondiskriminatif (Idrus, 2004: 69).

Sebagaimana telah dikemukakan diatas bahwa eksistensi manusia sebagai makhluk yang termulia diantara makhluk-makhluk yang lain dan ia dijadikan oleh Allah dengan sebaik-baiknya bentuk, baik fisik maupun psikisnya serta dilengkapi dengan berabagai alat potensial, dan potensi-potensi daasar (fitrah). Sebagaimana di ungkapkan dalam QS. at-Tin (95) ayat 4: "Sesunngguhnya kami telah menciptakan manusia dalam bentuk yang sebaikbaiknya".

Potensi-potensi tersebut perlu di kembangkan dan di aktualisasikan seoptimal mungkin melalui proses pendidikan. Disinilah pendidikan mempunyai peran penting dan strategis dalam mengembangkan potensi positif tersebut secara optimal dan seimbang. Disamping itu, harus disadari pula bahwa manusia juga mempunyai sifat-sifat negatif. ${ }^{10}$

Maka pendidikan juga bertugas untuk membimbing dan mengarahkan manusia agar mampu mengendalikan diri dan menghilangkan sifat-sifat negatif yang melekat pada dirinya agar tidak sampai mendominasi dalam kehidupannya, sebaliknya harus mengaktualisasikan sifat-sifat positif nya yang tercermin dalam kepribadiannya (Muhaimin, 2004: 27).

Langgulung (2003:1-2) menyatakan bahwa hakikat pendidikan adalah pewarisan kebudayaan dari generasi ke generasi dan pengembangan potensi-potensi yang terpendam dan tersembunyi. Dengan kata lain, masyarakat mempunyai nilai-nilai budaya yang ingin di salurkan dari generasi ke generasi agar identitas masyarakat tersebut tetap terpelihara.

Pendidikan adalah proses humanisasi seseorang dalam kehidupan keluarga, masyarakat, yang berbudaya kini dan masa depan (Tilaar, 2004: 40). Pendidikan sebagai proses hominisasi, dimaksudkan pengembangan manusia sebagai makhluk hidup. Makhluk manusia harus di besarkan agar dia dapat berdiri sendiri dan memenuhi kebutuhan hidup nya seperti kehidupan biologis yang membutuhkan makanan bergizi, kebutuhan seks, kehidupan ekonomis, termasuk mempunyai lapangan kerja sendiri. Pendidikan sebagai proses humanisasi berarti manusia itu bukan hanya sekedar dapat hidup dan makan, tetapi juga dia bertanggung jawab terhadap dirinya sendiri dan terhadap kesejahteraan masyarakatnya. Oleh sebab itu, dia harus belajar untuk bertanggung jawab, mengenal dan menghayati serta melaksanakan nilai-nilai moral (knowing is doing) (Tilaar, 2002: 171).

Al-Ahwani (1968:9), mengatakan bahwa tujuan pendidikan Islam adalah perpaduan yang menyatu antara pendidikan jiwa, membersihkan ruh, mencerdaskan akal, dan menguatkan jasmani. Disini menjadi bidikan dan fokus pendidikan Islam yang di kemukakan oleh al-Ahwani adalah soal keterpaduan. Hal tersebut bisa di mengerti karena keterbatasan atau disintegrasi tidak menjadi watak dari Islam.

Al-Shaibani (t.th:292) mengemukakan bahwa tujuan tertinggi dari pendidikan Islam adalah persiapan untuk kehidupan dunia dan akhirat. Tujuan pendidikan adalah untuk memproses manusia yang siap untuk berbuat dan memakai fasilitas dunia ini guna beribadah kepada Allah, bukan manusia yang siap dipakai oleh lembaga, pabrik atau yang lainnya. ${ }^{11}$ Jika yang terakhir ini yang dijadikan tujuan dan orientasi pendidikan, maka pendidikan hanya di tujukan sebagai alat produksi tenaga kerja dan memperlakukan manusia bagaikan mesin dan robot. Pendidikan seperti ini tidak akan mampu mencetak manusia terampil dan kreatif yang memiliki kebebasan dan kehormatan.

\footnotetext{
${ }^{10}$ Raudhah, Vol 11 no 1 (2018) | 601

${ }^{11}$ Raudhah, Vol 12 no 1 (2018) | 602
} 
Volume 3 Nomor 2 Edisi Desember 2018

P-ISSN : 2541-3686

Al-'Ainaini (1980: 167-193) menyatakan bahwa hakikat pendidikan Islam adalah perpaduan antara pendidikan jasmani, akal, akidah, akhlak, perasaan, keindahan, dan kemasyarakatan. Qutub (t.th: 17) menyatakan bahwa pendidikan Islam adalah menumbuhkan dan mengembangkan (fitrah) manusia secara utuh dan menyeluruh dengan tidak ada yang tertinggal dan terabaikan sedikitpun; dari aspek jasmani, akal, dan ruhaninya, kehidupan materil, dan imateril, dan pada seluruh aktivitas hidupnya di muka bumi.

Al-Kilani (1998:13) menyatakan bahwa tujuan pendidikan adalah terwujudnya perubahan-perubahan yang dikehendaki dalam perilaku individu dan membiasakannya dalam kehidupan masyarakat, yaitu individu yang mempunyai karakter atau kepribadian intelek dan berbudaya tinggi. Karakter tersebut menjadi basis karakter masyarakat yyang berperadaban tinggi.

Freire (1968:19) mengemukakan bahwa pendidikan bertujuan untuk membangkitkan kesadaran manusia bahwa manusia itu mempunyai martabat dan kebebasan dan tidak menyerah kepada berbagai jenis penindasan. Pendidikan adalah proses pembebasan. Dapat mengembangkan sumber daya manusia yang berkualitas yang dilandasi dengan nilai-nilai Ketuhanan (ilahiyyah), dan berbudaya. Dari kerangka ini, maka pendidikan Islam harus, mengembangkan pendidikan yang integralistik, humanistik, pragmatis, dan berakar pada budaya.

Konsep pendidikan integralistik, secara utuh berorientasi pada nilai-nilai Ketuhanan (rabbaniyyah ilahiyyah), kemanusiaan (insaniyyah), dan lingkungan alam bagi perwujudan kehidupan rahmatan lil a-lamin. Konsep pendidikan humanistic, pendidikan yang berorientasi dan memandang manusia sebagai manusia, dengan menghargai hak-hak asasi manusia, hak untuk menyuarakan pendapat, mengembangkan potensi beerfikir, berkemauan dan bertindak sesuai dengan nilai-nilai luhur kemanusiaan. Konsep pendidikan pragmatis, memandang manusia sebagai makhluk fungsional yang perlu melangsungkan, mempertahankan, mengembangkan hidup nya baik secara jasmani maupun rohani serta mewujudkan manusia yang memahami eksistensinya dengan memiliki kepribadian yang unggul, harga diri, percaya kepada kemampuan sendiri, membangun budaya berdasarkan budaya sendiri yang di dasarkan pada nilai-nilai ilahiyyah (Barnadib, 2003: xi-xii).

Al-Abrasyi (t.th:5) mengemukakan bahwa proses pendidikan Islam banyak di pengaruhi oleh prrinsip-prinsip demokrasi. Demokrasi dan pembebasan memberikan kontribusi penting bagi pencapaian tujuan pendidikan Islam. Karena prinsip utama pendidikan adalah mengembangkan berfikir bebas dn mandiri secara demokratis dengan memperhatikan kecenderungan peserta didik secara individual, baik aspek kecerdasan akal maupun bakatnya. Kurikulum pendidikan Islam hendaknya mengacu kea rah pengembangan aspek spiritual, aspek moral, dan aspek intelektual serta aspek professional. ${ }^{12}$

Mulkhan (2002:86) menyatakan bahwa pendidikan humanistik berakar dari keunikan personalitas manusia, dan humanisasi pendidikan dapat dijalankan dengan bentuk demokratisasi pendidikan. Demokratisasi pendidikan menjadi syarat mutlak bagi terbentukya dialogis dan humanis.

Sejalan dengan pemikiran tersebut diatas, Rosyada (2004:20) menyatakan bahwa model pembelajaran humanis dapat terwadahi dalam model sekolah demokratis. Lebih lanjut di ungkapkan bahwa medel sekolah demokratismemiliki ciri-ciri: pertama, akuntabilitas, yaitu kebijakan-kebijakan sekolah-sekolah dalam semua aspeknya dapat di pertanggungjawabkan kepada publik; kedua, pelaksanaan tugas guru senantiasa berorientasi pada peserta didik, guru akan memberikan pelayanan secara individual, berbagai kesulitan peserta didik akan menjadi perhatian guru; dan ketiga, keterlibatan masyarakat dalam sekolah, yaitu sistem pendidikan

\footnotetext{
${ }^{12}$ Raudhah, Vol 13 no 1 (2018) | 613
} 


\section{Konteks Syukur Sebagai Paradigma Dalam Perspektif Pendidikan Islam \\ Moh. Fuadi}

merupakan refleksi dari keinginan masyarakat. Masyarakat akan berpartisipasi dalam pendidikan dan akan responsive dengan berbagai persoalan sekolah.

\section{Syukur sebagai Motivasi Pengembangan Potensi Psikologis Manusia}

Dari proses kejadiannya manusia itu terdiri atas dua subtansi, yaitu; subtansi materi (jismiyah/jasad) dan imateri (ruhani/psikis). Subtansi jasad yang berbahan dasar materi merupakan bagian dari alam semesta ciptaan Allah yang dalam pertumbuhan dan perkembangannya tunduk dan patuh pada sunnatullah (aturan, ketentuan, hokum Allah yang berlaku di alam semesta); sementara subtansi ruhani manusia merupakan pancaran atau peniupan ruh (ciptaan-Nya) ke dalam diri manusia sehingga manusia merupakan benda organic yang mempunyai hakikat kemanusiaan serta mempunyai berbagai alat potensial dan fitrah (fitrah) (Muhaimin, 2004:12). Kenyataan di atas, di tegaskan oleh al-Farabi (1926:37) yang memahami bahwa manusia terdiri atas dua unsur, yaitu: (1) satu unsur berasal dari 'alam al-Khalaq; dan (2) satu unsur berasal dari 'alam al-amr (ruh dari perintah Tuhan).

Manusia yang terdiri atas substansi, itu telah di lengkapi dengan alat-alat potensial dan potensi-potensi dasar atau disebut fitrah (fitrah). Berkaitan dengan fitrah manusia, Jalal (1997: 103-110) telah mengkaji ayat-ayat al-Qur'an yang berkaitan dengan alat-alat potensial yang di anugerahkan oleh Allah kepada manusia untuk meraih ilmu pengetahuan. Masingmasing alat itu saling berkaitan dan melengkapi dalam mencapai ilmu pengetahuan. ${ }^{13}$ Alatalat tersebut adalah sebagai berikut:

a. Al-Lams dan al-shum, yaitu alat perabah dan alat penciuman/pembau. Sebagaimana di terangkan dalam QS. al-an'am (6) ayat 7: "Dan kalau kami turunkan kepadamu tulisan diatas kertas, lalu mereka dapat menyentuhnya dengan tangan mereka sendiri, tentula orang-orang kafir itu berkata: "ini tidak lain hanyalah sihir semata".

b. Al-sam'u, yaitu alat pendengaran. Penyebutan alat ini di hubungkan dengan penglihatan dan qalb, yang menunjukkan adanya saling melengkapi antara berbagai alat itu untuk mencapai ilmu pengetahuan. Sebagaimana diterangkan dalam QS. al-isra' (17) ayat 36: "Dan janganlah kamu mengikuti apa yang tidak kamu tidak mempunyai pengetahuan tentangnya. Sesungguhnya pendengaran, penglihatan dan hati, semuanya itu akan di minta pertanggung jawabannya".

c. Al-abshar, yaitu alat penglihatan. Banyak ayat al-Qur'an yang menyeru manusia untuk melihat dan merenungkan apa yang di lihatnya, sehingga dapat mencapai hakikatnya. Lihat QS. al-A'raf (7) ayat 185: “Dan apakah mereka tidak memperhatikan kerajaan langit dan bumi dan segala sesuatu yang di ciptakan Allah, dan kemungkinan telah dekatnya kebinasaan mereka? Maka kepada berita manakah lagi mereka akan beriman sesudah Al-Qur'an itu?"

d. Al- 'aql, yaitu akal atau daya berfikir. Al-Qur'an memberikan perhatian khusus terhadap penggunaan akal dalam berfiikir. Sebagaimana diterangkan dalam QS. Ali 'Imran (3) ayat 191:

(Yaitu) orang yang mengingat Allah sambil berdiri atau duduk ayau dalam keadaan berbaring dan mereka memikirkan tentang penciptaan langit dan bumi (seraya berkata): "Ya Tuhan kami, tidaklah Engkau menciptakan ini dengan siasia, Maha Suci Engkau, Maka peliharalah kami dari siksa neraka.

Al-Qur'an juga menjelaskan bahwa Islam tegak diatas pemikiran (QS. al-An'am (6) : 50). Dalam al-Qur'an dinyatakan bahwa penggunaan akal memungkinkan diri manusia untuk terus ingat (dzikir) dan memikirkan atau merenungkan ciptaan-Nya (QS. ar-Rad (13) : 19). ${ }^{14}$

\footnotetext{
${ }^{13}$ Raudhah, Vol 14 no 1 (2018) | 624

${ }^{14}$ Raudhah, Vol 15 no 1 (2018) | 625
} 
Volume 3 Nomor 2 Edisi Desember 2018

P-ISSN : 2541-3686

Penggunaan akal memungkinkan manusia mengetahui tanda-tanda (kebesaran/keagungan) Allah serta mengambil pelajaran dari padanya. Dalam beberapa ayat, kata al-Nuha digunakan sebagai makna al-'Ukul. Sebagaimana terlihat dalam QS. Thaha (20) ayat 53-54:

Yang telah menjadikan bagimu bumi sebagai harapan dan yang telah menjadikan bagimu di bumi itu jalan-jalan, dan menurunkan dari langit air hujan. Maka kami tumbuhkan air hujan itu berjenis-jenis dari tumbuh-tumbuhan yang bermacammacam. Makanlah dan gembalakanlah binatang-binatangmu. Sesungguhnya pada yang demikian itu, terdapat tanda-tanda kekuasaan Allah bagi orang-orang yang berakal.

e. Al-qalb, yaitu hati. Hal ini termasuk alat ma'rifah yang diguakan manusia untuk dapat mencapai ilmu. Sebagaimana diterangkan dalam QS. Muhammad (47) ayat 24: "Maka apakah mereka tidak memperhatikan Al-Qur'an ataukah hati mereka terkunci?".

Qalbu ini mempunyai kedudukan khusus dalam ma'rifat ilahiyah, dengan qalbu manusia dapat meraih berbagai ilmu serta ma'rifah yang di serap dari sumber ilahi. Wahyu itu sendiri di turunkan ke dalam qalbu Nabi Muhammad Saw. (QS. as-Shu'ara (26): 192194).

Adapun pengaruh syukur terhadap potensi kemanusiaan tersebut adalah, bahwa dengan syukur manusia akan menyadari betul manfaat dari potensi yang ia miliki. Kenyataan ini secara psikologis akan berpengaruh terhadap peningkatan kkinerja manusia, sebagai makhluk yang dapat di didik. Dalam kerangka inilah syukur dapat dijadikan sebagai motivasi bagi anak untuk memaksimalkan potensi yang dimilikinya.

Dalam psikologi pendidikan, motivasi merupakan komponenyang penting bagi proses belajar manusia. Berbagai tindakan dalam proses pendidikan terkadang di arahkan untuk memunculkan motivasi belajar anak, seperti pujian, piagam prestasi dan sebagainya (Soemanto, 2003:188). Motivasi ini diharapkan dapat membawa perubahan tingkah laku yang diharapkan bagi anak.

Masalah motivasi dalam pembelajaran cukup komplek, sementara tidak ada aturan khusus yang dapatt diterapkan dalam melakukan motivasi, karena itu guru seharusnya peka terhadap upaya motivasi ini. ${ }^{15}$ Hillgard misalnya mengungkapkan tidak ada obat yang mujarab untuk dapat meningkatkan potensi belajar anak di lingkungan sekolah (Hillgard, 1956: 37). Untuk tu upaya memotivasi belajar pada dasarnya beragam tergantung pada individu anak sendiri. Dan salah satu yang dapat dilakukan adalah dengan menanamkan rasa syukur dalam diri anak terhadap potensi yang mereka miliki, sehingga mereka dapat memaksimalkan potensi yang dimiliki sebaik mungkin.

Sebagai contoh, anak di anjurkan untuk mensyukuri bahwa mereka telah diberikan nikmat berupa potensi untuk mendengar, melihat, dan berfikir. Rasa syukur anak ini dapat di aplikasikan melalui ucapan dan juga perbuatan. Bahwa anak seharusnya dapat menggunakan potensi yang dimiliki dengan sebaik mungkin, khususnya terkait dengan proses pembelajaran. Dengan rasa syukur yang tertanam dalam diri anak, mereka akan menyadari berbagai potensi dalam diri mereka yang mereka kembangkan lebih jauh.

\section{Konstruksi Paradigma Pendidikan Islam Berbasis Syukur}

Telah dijelaskan bahwa manusia merupakan ruh, serta dilengkapi dengan potensipotensi dasar yang begitu lengkap. Dalam kenyataan ini maka manusia sudah sepantasnya dapat bersyukur kehadirat Allah, dengan cara berupaya mengaktualisasikan dan menumbuh kembangkan segenap potensi yang dimiliki dalam kehidupan nyata di dunia ini. Salah satu cara terbaik yang dapat dilakukan untuk ini adalah melalui proses pendidikan.

\footnotetext{
${ }^{15}$ Raudhah, Vol 16 no 1 (2018) | 636
} 


\section{Konteks Syukur Sebagai Paradigma Dalam Perspektif Pendidikan Islam \\ Moh. Fuadi}

Pendidikan dalam Islam, antara lain berfungsi untuk mengembangkan potensi yang dimiliki manusia seoptimal mungkin untuk dapat di fungsikan sebagai sarana bagi pemecahan masalah-masalah hidup dan kehidupan, pengembangan ilmu pengetahuan dan tehnologi serta budaya manusia, dan pengembangan sikap iman dan taqwa kepada Allah. Kenyataan ini sebenarnya memperlihatkan bahwa pendidikan Islam pada dasarnya terkait dengan paradigm syukur, dimana kesadaran terhadap besarnya potensi yang diberikan Allah kepada manusia, menjadikan manusia mestinya dapat bersyukur dengan upaya memaksimalkan potensi yang dimiliki. Salah satunya adalah melalui pendidikan.

Prinsip di atas dapat di gali dari ajaran syukur dalam Islam, bahwa syukur akan berkonsekuensi pada "nilai tambah" atau "added value". Sehingga seseorang tidak dikatakan bersyukur jika tindakannya tidak memunculkan nilai tambah dalam bentuk apapun (Abdulrahim, 37-38). ${ }^{16} \mathrm{Hal}$ ini di tegaskan dalam al-Qur'an QS. Ibrahim (14) ayat 7: "Dan (ingatlah juga), tatkala Tuhanmu memaklumkan: "Sesungguhnya jika kamu bersyukur, pasti kami akan menambah (nikmat) kepadamu, dan jika kamu mengingkari (nikmat-ku, maka sesungguhnya azab-Ku sangat pedih". Dan juga QS. an-Nahl (16) ayat 78: "Allah Swt. Telah mengeluarkan kamu dari rahim ibumu dalam keadaan tidak mengetahui sesuatu apapun, dan Dia telah member kamu pendengaran, penglihatan dan hati, agar kamu bersyukur".

Karena itu pendidikan Islam pada dasarnya berparadigma syukur, yang membawa konsekuensi pada kegiatan untuk mengembangkan segenap potensi jasmaniah dan ruhaniah yang dimiliki oleh manusia seoptimal mungkin. Hal ini sesuai dengan akhir kata ayat yang disebutkan diatas "La'allakum tasykuruun" (supaya kamu bersyukur). Hal ini sesuai pula dengan keterangan yang diberikan oleh Muhammad Abduh, bahwa yang dinamakan syukur itu adalah menggunakan nikmat dan anugerah Allah sesuai dengan fungsinya, dan sesuai dengan kehendak yang menganugerahkannya, yaitu Allah (Muhaimin, 2004:16).

Paradigma syukur semakin kentara dalam pendidikan Islam, ketika segenap pengembangan potensi yang dilakukan diarahkan sepenuhnya sebagai penunjang bagi manusia agar mampu menjalankan tugas dan fungsinya sebagaimana yang telah di amanatkan Allah, yaitu sebagai hamba Allah ('abdullah) dan khalifah-Nya di bumi. Dalam konteks ini, adalah upaya menumbuhkan dan mengembangkan (fitrah/potensi) manusia secara utuh, baik dari aspek jasmani, akal, dan ruhaninya, kehidupan materil dan imateril, dan pada seluruh aktivitas hidupnya di muka bumi.

Dengan memperhatikan kesatuan potensi yang dimiliki manusia, pendidikan Islam memahami bahwa semua potensi manusia harus di kembangkan secara seimbang, konsekuensinya adalah pendidikan Islam harus dapat diarahkan untuk membina semua potensi tersebut. Berkaitan dengan hal ini Shihab (2004: 173) menjelaskan bahwa pembinaan jasmania akan menghasilkan keterampilan, pembinaan akalnya aka menghasilkan ilmu, dan pembinaan ruhani akan menghasilkan kesucian dan etika. ${ }^{17}$ Dengan penggabungan unsurunsur tersebut, terciptalah makhluk dwi dimensi dalam satu keseimbangan, dunia dan akhirat, ilmu dan iman. Itu sebabnya dalam pendidikan Islam di kenal dengan istilah 'adab al-din dan 'adab al- Dunya.

Dengan demikian terdapat korelasi antara "upaya pengembagan potensi diri" "peningkatan kualitas kepribadian". Dengan mengembangkan potensi akal ('aql) akan menghasilkan ilmu, dengan mengembangkan potensi hati (qalb atau fu'ad) akan menghasilkan etika dan moral atau akhlak.

Jelaslah bahwa syukur pada dasarnya merupakan salah satu dari paradigm pendidikan Islam yang penting. Jika di rujuk dari makna asalnya, keduanya memiliki keterkaitan yang logis. Pendidikan Islam (tarbiyah) mempunyai makna menumbuhkan dan mengembangkan

\footnotetext{
${ }^{16}$ Raudhah, Vol 17 no 1 (2018) | 647

${ }^{17}$ Raudhah, Vol 18 no 1 (2018) | 648
} 
Volume 3 Nomor 2 Edisi Desember 2018

P-ISSN : 2541-3686

segenap potensi manusia kea rah peningkatan kualitas kepribadian. Sementara syukur bermakna gambaran dalam benak tentang nikmat dan menampakkannya ke permukaan, atau membuka sehingga ia merupakan lawan dari kata kafara yang berarti menutup (salah satu artinya adalah) melupakan nikmat dan menutup-nutupinya (Shihab,2006:2016). Sebagai akibat dari tindakan bersyukur adalah terjadinya pertambahan (al-ziyadah), perkembangan, menjadi banyak, lebat, dan subur. Makna-makna tersebut merupakan nilai tambah (addedvalue) yang diperoleh dari tindakan bersyukur.

Jika syukur dijadikan sebagai paradigm pendidikan Islam, maka akan memunculkan pemahaman bahwa pendidikan Islam sebagai bentuk tindakan syukur terhadap nikmat Allah melalui upaya pengembangan segenap potensi dari manusia harus dapat memunculkan addedvalue, yaitu terjadinya peningkatan kualitas kepribadian manusia. Kualitas kepribadian itu dapat berupa pribadi yang utuh ataupun insane al-kamil, yaitu pribadi yang memilki jasmani yang sehat, kuat dan terampil, memiliki akal yang cerdas dan pandai (berilmu), memiliki hati yang penuh dengan nilai-nilai keimanan dan ketakwaan kepada Allah, serta memilki akhlak yang mulia sebagaimana akhlak rasululullah.

Paradigm syukur ini berlawanan dengan paradigm kafara dalam konteks pendidikan, yaitu keadaan manusia yang menutup-nutupi nikmat segenap potensi yang ada pada dirinya, sehingga potensi tersebut di biarkan begitu saja dan tidak di kembangkan secara maksimal. Paradigma ini jika diaplikasikan dalam pendidikan akan memunculkan sikap malas berolahraga, malas berlatih, malas belajar, etos membaca dan meneliti yang rendah, tidak bersosialisasi dan sebagainya. Konsekuensi dari tindakan kufur terhadap segenap potensi tersebut adalah terjadinya kepribadian yang lemah dan tidak utuh berupa fisik yang lemah, gampang sakit, perasaan minder, pesimis, tidak memiliki keterampilan, berwawasan sempit, bodoh dan terbelakang. Hal inilah yang "kemungkinan" di istilahkan dalam al-Qur'an sebagai inna'azabilasyadid.

\section{Simpulan}

Berdasarkan penjelasan diatas, jelaslah bahwa syukur merupakan salah satu dari paradigm pendidikan islam yang di tarik dari salah satu nilai-nilai ajaran Islam yang utuh. Hahikat syukur sendiri dalam Islam merupakan sikap dan rasa terima kasih atas segala nikmat yang dianugerahkan Allah kepada manusia, yang di aktualisasikan melalui ucapan alhamdulillah dan juga perbuatan yang mengarah pada upaya untuk memanfaatkan nikmat yang diberikan oleh Allah secara optimal sesuai dengan fungsi dan tujuan penciptaannya. Tindakan syukur ini pada dasarnya terbentuk dari kesadaran (pengetahuan dan perenungan) yang mendalam tentang nikmat-nikmat yang telah di anugerahkan Allah kepada manusia. ${ }^{18}$

Sebagai paradigm pendidikan Islam, syukur potensi yang dimiliki manusia secara optimal dalam kehidupan nyata, sesuai dengan fungsi dan tujuan penciptaan potensi yang ada. Konsekuensinya adalah adanya nilai tambah (al-ziyadah added value), nilai manfaat, dan nilai guna (use value) bagi manusia yang mampu bersyukur. Lebih jauh, syukur dapat menjadi motivasi dalam pendidikan, dalam upaya pengembangan diri, peningkatan kualitas kepribadian, dan pengembangan segenap potensi diri yang diarahkan bagi kemaslahatan diri sendiri, keluarga, bangsa, agama dan lingkungan alam maupun sosial.

Sebagai catatan akhir dapat dikatakan bahwa sebagai nilai-nilai luhur dalam ajaran Islam pada dasarnya dapat di kembangkan menjadi paradigma pendidikan Islam yang sangat berguna dalam pengembangan pendidikan Islam itu sendiri. Konsep syukur misalnya ternyata memiliki kandundan nilai yang dalam ketika ia dijadikan basis world view ataupun paradigma pendidikan Islam.

\footnotetext{
${ }^{18}$ Raudhah, Vol 19 no 1 (2018) | 659
} 


\section{Konteks Syukur Sebagai Paradigma Dalam Perspektif Pendidikan Islam}

Moh. Fuadi

\section{DAFTAR PUSTAKA}

Al-Qur'an al- Karim

'Abdulrahim, Muhammad 'Imaduddin. 2002. Islam sistemNilai Terpadu. Gema Insani Press, Jakarta.

'Ainanini, 'Ali Khalil Abu. 1980. Falsafahal-Tarbiyah al- Islamiyah. Dar al- Fikr al-'Arabi, Kairo.

Abrasyi, Muhammad 'Athiyah. t.th. Al-Tarbiyah al-Islamiyah. Dar Fikr al-'Arabi, Beirut.

Ahwani, Ahmad Fu'ad. 1968. al-Tarbiyah fi al-Islam. Dar al-Ma'arif, Kairo.

Aldridge, Jerry and Renita Goldman. 2002. Current Issues and Trend in education. Allyn and Bacon, Boston.

Aravik, Havis, Pengantar Studi Islam, Palembang: Rafah Press, 2018.

Attas, Muhammad al-Naquib. 1988. Konesp Pendidikan dalam Islam. Mizan, Bandung.

Baharudin dan Moh. Makin. 2007. Pendidikan Humanistik. Al-Ruzz Media Group, Yogyakarta.

Bahreis, Hussein. 1981. Ajaran-ajaran Akhlak Imam al-Ghazali. al-Ikhlash, Surabaya.

Choudhury, Masudul Alam. 2007. The Universal paradigm and the Islamic World-System. World scientific Publisging, Singapore.

Farabi. 1926. "Fusuh al-Hikam” dalam Rasa'il al-Farabi.t.p. Hyderabad.

Freire, Paulo. 1968. Pedagogy of the Oppressed.

1998. Pedagogy of Hope

1998. Pedagogy of Freedom.

Ghazali, Syeikh Muhammad. 2004 Nahw Tafsir Maudhui'y liSuwar al-Qur'an, Tafsir Tematik dalam al-Qur'an. Gaya Media Pratama, Jakarta.

Hillgard, ER. 1956. Theories of Learning. Appletton Century, New York.

Idrus, Junaidi. 2004. Rekonstruksi Pemikiran Nurcholish Madjid: embangun Visi Misi Baru Islam Indonesia. Lagung Pustaka, Yogyakarta.

Jalal, 'Abdul Fattah. 1997. Min-al-Ushul al-Tarbawiyah fi al-Islam. Dar al-Kutub, Mesir.

Khauj, Abdullah M. 1980. Humanistic Psicology and Islamic Relegion: A Critical Analysis. Boston University School of Education.

Khun, Thomas S. (1962), penerjemah: Tjun Surjaman. 2005. The Structure of scientific Revolution: Peran Paradigma dalam Revolusi Sains. Remaja Rosdakarya, Bandung.

Kilani Majid 'Arsan. 1998. Ahdaf al-Tarbiyah al-Islamiyah. Libanon: Mu'assah al-Riyyan, Beirut.

Kuntowijoyo. 1991. Paradigma Islam. Mizan, Bandung.

Lacey, AR. 1996. A Dictipnari of Philosophy. Routledge, London.

Langgulung, Hasan. 2003. Asas-asas Pendidikan Islam. Pustaka Al-Husna, Jakarta. 
RAUDHAH Proud To Be Professionals Jurnal Tarbiyah)damiyah

Volume 3 Nomor 2 Edisi Desember 2018

P-ISSN : 2541-3686

Madjid, Nurcholish. 2000. Masyarakat Religius: Membumikan Nilai-nilai Islam dalam Pendidikan Masyarakat. Paradigma, Jakarta.

Malik, Fadjar. 2005. Holistika Pemikiran Pendidikan. Raja Grafindo Persada, Jakarta.

Muhaimin, et.al. 2004. Paradigma Pendidikan Islam: Upaya Mengefektifkan Pendidikan Agama Islam di Sekolah. Remaja Rosdakarya, Bandung.

Mulkhan, Abdul Munir. 2002. Nalar Spiritual Pendidikan: Solusi Problem Filosofis Pendidikan Islam. Tiara Wacana, Yogyakarta.

Munawir, ahmad Warson. t.th. Kamus al- Munawir Arab Indonesia Terlengkap. Pustaka Progresif, Surabaya.

Muthahhari, Murtadha. 1997. Perspektif Qur'an tentang manusia dan Agama. Mizan, Bandung.

Nahlawi, Abdurrahman. 1992. Prinsip-prinsip dan Metode Pendidikan Islam dalam Keluarga, di Sekolah, dan di Masyarakat. Di Ponegoro, Bandung.

Qutub, Muhammad. t.th. Manhaj al-Tarbiyah al-Islamiyah. Dar al-Qalam, Mesir.

Ramayulis. 2008. Ilmu Pendidikan Islam. Kalam Mulia, Jakarta.

Ramly, Najamuddin. 2005. Membangun Pendidikan yang memberdayakan dan Mencerahkan. Grafindo Khazanah Ilmu, Jakarta.

Ridha, Rashid. 1373 H. Tafsir al-Manar. Dar al-Manar, Mesir.

Rosyada, dede. 2004. Paradigma Pendidikan Demokratis: Sebuah Pelibatan Masyarakat dalam Penyelenggaraan Pendidikan. Kencana, Jakarta.

Sanaky, Hujair AH. 2003. Paradigma Pendidikan Islam: Membangun Masyarakat Madani Indonseia. Safiria Insania Press, Yogyakarta.

Saibani 'Umar Muhammad al-Toumy. t.th. Falsafah al-Tarbiyah al-Islamiyah. Al-Shyirkah al-'Ammah li al-Nasr wa Tauzi'I al-I'lan, Tripoli.

Shaleh, Muhammad. 2008. Paradigma Pendidikan Islam, Jurnal al-Ta'dib, vol.1. No.1

Shihab, M. Quraish. 2004. Membumikan al-Qur'an: Fungsi dan Peran Wahyu dalam Kehidupan Masyarakat. Mizan, Bandung.

2006. Wawasan Al-Qur'an: Tafsir Maudhu'I atas Berbagai Persoalan Umat. Mizan, Bandung.

Soemanto, Wasty. 1990. Psikologi Pendidikan (Landasan Kerja Pemimpin Pendidikan). Rineka Cipta, Jakarta.

Tilaar, H.A.R. 2004. Paradigma Baru Pendidikan Nasional. Rineka Cipta, Jakarta. 
Konteks Syukur Sebagai Paradigma Dalam Perspektif Pendidikan Islam Moh. Fuadi 